\title{
From nanotechnology to nanomedicine: applications to cancer research
}

Citation for published version (APA):

Seigneuric, R., Markey, L., Nuyten, D. S., Dubernet, C., Evelo, C. T. A., Finot, E., \& Garrido, C. (2010). From nanotechnology to nanomedicine: applications to cancer research. Current Molecular Medicine, 10(7), 640-652. https://doi.org/10.2174/156652410792630634

Document status and date:

Published: 01/10/2010

DOI:

10.2174/156652410792630634

Document Version:

Publisher's PDF, also known as Version of record

Document license:

Taverne

Please check the document version of this publication:

- A submitted manuscript is the version of the article upon submission and before peer-review. There can be important differences between the submitted version and the official published version of record.

People interested in the research are advised to contact the author for the final version of the publication, or visit the DOI to the publisher's website.

- The final author version and the galley proof are versions of the publication after peer review.

- The final published version features the final layout of the paper including the volume, issue and page numbers.

Link to publication

\footnotetext{
General rights rights.

- You may freely distribute the URL identifying the publication in the public portal. please follow below link for the End User Agreement:

www.umlib.nl/taverne-license

Take down policy

If you believe that this document breaches copyright please contact us at:

repository@maastrichtuniversity.nl

providing details and we will investigate your claim.
}

Copyright and moral rights for the publications made accessible in the public portal are retained by the authors and/or other copyright owners and it is a condition of accessing publications that users recognise and abide by the legal requirements associated with these

- Users may download and print one copy of any publication from the public portal for the purpose of private study or research.

- You may not further distribute the material or use it for any profit-making activity or commercial gain

If the publication is distributed under the terms of Article $25 \mathrm{fa}$ of the Dutch Copyright Act, indicated by the "Taverne" license above, 


\title{
From Nanotechnology to Nanomedicine: Applications to Cancer Research
}

\author{
R. Seigneuric ${ }^{\star 1,1,6}$, L. Markey ${ }^{1,6}$, D.S.A. Nuyten ${ }^{2}$, C. Dubernet $^{3}$, C.T.A. Evelo ${ }^{4}$, E. Finot ${ }^{1,6}$ \\ and C. Garrido ${ }^{5,6}$
}

${ }^{1}$ Département Nanosciences, Laboratoire Interdisciplinaire Carnot de Bourgogne, CNRS-UMR 5209, 9 , Avenue Alain Savary, BP 47870, 21078 DIJON Cedex, France

${ }^{2}$ Bristol-Myers Squibb Company, Discovery Medicine \& Clinical Pharmacology, P.O. Box 4000, Mail Stop E 1203, Princeton, NJ 08543-4000, USA

${ }^{3}$ Univ Paris-Sud, UMR8612, Châtenay-Malabry, F-92296, France

${ }^{4}$ Department of Bioinformatics - BiGCaT, Maastricht University, P.O. Box 616, UNS50 Box 19, NL-6200 MD Maastricht, The Netherlands

${ }^{5}$ Heat Shock Proteins \& Cancer, INSERM, UMR 866 IFR 100, Faculty of Medicine, 7 Boulevard Jeanne D'Arc, 21000 Dijon, France

${ }^{6}$ Université de Bourgogne, Dijon, France

\begin{abstract}
Scientific advances have significantly improved the practice of medicine by providing objective and quantitative means for exploring the human body and disease states. These innovative technologies have already profoundly improved disease detection, imaging, treatment and patient follow-up. Today's analytical limits are at the nanoscale level (one-billionth of a meter) enabling a detailed exploration at the level of DNA, RNA, proteins and metabolites which are in fact nano-objects. This translational review aims at integrating some recent advances from micro- and nano-technologies with high potential for improving daily oncology practice.
\end{abstract}

Keywords: Nanomedicine, circulating tumour cell, nanoparticle, EPR effect.

\section{INTRODUCTION}

Nanotechnology (from nano, 'dwarf' in Greek) was envisioned by the physicist and Nobel laureate Richard Feynman in his seminal lecture "there is plenty of room at the bottom" in 1959 [1-3]. It provides scientists with new tools for the investigation of objects in the range of -typically but not exclusively- $1 \mathrm{~nm}$ to $100 \mathrm{~nm}$ : the typical scale of biologically relevant molecules like proteins, enzymes, receptors, haemoglobin and antibodies for instance (see Fig. (1)). Nanotechnology, coined in 1974, refers to the handling and/or engineering of nano-objects on the scale of molecules [4], and brings at least 2 major attractive features to existing techniques. Synthetic nanoscale materials are inherently small, with at least one dimension in the 1$100 \mathrm{~nm}$ range [5] so they can cross biological barriers [6] including the blood-brain barrier [5], transit out blood vessel walls [5] or the cell membrane by different uptake mechanisms [7]. They can therefore interact with a wide panel of biological entities (e.g.: from proteins to cells). Also, nano-objects exhibit tuneable physical (e.g.: electrical, magnetic, optical, mechanical), chemical (e.g.: reactivity [8], melting point

${ }^{*}$ Address correspondence to this author at the Nanosciences Department Carnot Institute of Burgundy, CNRS-UMR 5209, 9, Avenue Alain Savary, BP 4787021078 DIJON Cedex, France; Tel: 333803990 67; Fax: 333803960 24;

E-mail: renaud.seigneuric@u-bourgogne.fr
[5]) or biological properties that are dramatically different from the same materials in larger scale forms $[3-5,8,9]$ due to modified quantum mechanical properties [5]. Depending on the type of applications, nano-objects can span different shapes (e.g.: nanospheres, nanotubes, nanorods, nanowires) and materials (e.g.: silica, gold, semiconductors, iron oxides, lipid- or polymer-based) so they can be hollow, porous or solid. These characteristics confer nanoobjects high interaction and transport capabilities, making them attractive tools for the design of biosensors, imaging contrast agents and/or therapeutic carriers.

To accelerate the war on cancer declared in 1971 by President Richard Nixon [10], the National Cancer Institute launched the Alliance for Nanotechnology in Cancer (http://nano.cancer.gov) in 2004. Massive fundings have been devoted to the development and improvement of novel nanotechnologies in order to reduce cancer mortality since then $[9,11,12]$. Convergence of nanotechnology and medicine recently led to an interdisciplinary field: nanomedicine, which brings together engineers, physicists, biologists, chemists, mathematicians, and physicians striving to improve detection, imaging and drug delivery devices. This review deals with some concrete recent developments concerning cancer detection and treatment enabled by micro- and nano-technologies. 


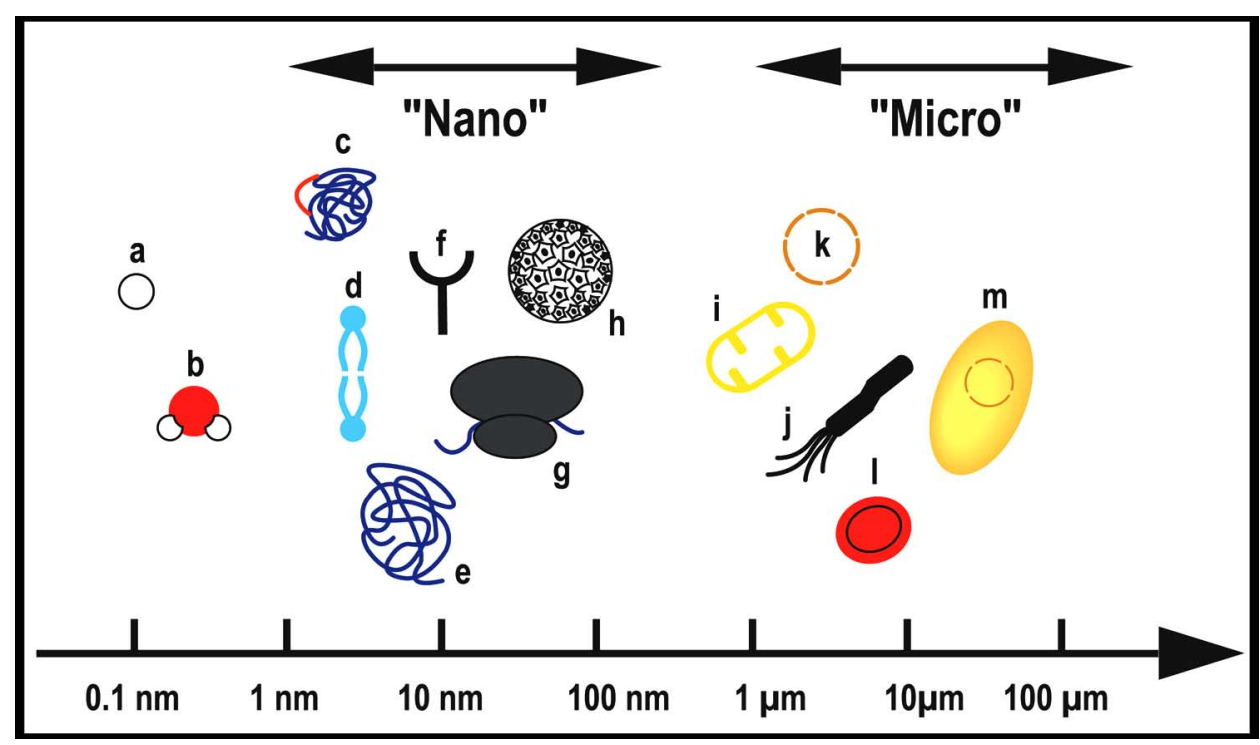

Fig. (1). Typical size of nano- and micro-objects (horizontal axis: log-scale) from left- to right: (a) Hydrogen atom ( 0.1nm), (b) water molecule (diameter: $\sim 0.4 \mathrm{~nm}$ ), (c) peptide aptamer (size $\sim 3 \mathrm{~nm}$ ), (d) lipid bilayer (thickness $\sim 5 \mathrm{~nm}$ ), (e) protein (size $\sim 10 \mathrm{~nm}$ ), (f) antibody (size $\sim 10 \mathrm{~nm}$ ), (g) ribosome (diameter $\sim 30 \mathrm{~nm}$ ), (h) human papillomavirus (diameter $\sim 60 \mathrm{~nm}$ ), (i) mitochondrium (length $\sim 1 \mu \mathrm{m}$ ), (j) Helicobacter pylori (length $\sim 3 \mu \mathrm{m})$, (k) nucleus (diameter $\sim 3 \mu \mathrm{m})$, (I) erythrocyte $($ diameter $\sim 8 \mu \mathrm{m})$, $(\mathrm{m})$ mammalian cell (diameter $\sim 20 \mu \mathrm{m})$.

\section{FROM BIOSENSORS TO CANCER DETECTION}

In the current clinical set-up, cancer detection relies mainly on the indirect quantification of proteins or the identification of a tumor mass of a few cubic millimetres already containing $\sim 10^{8}[13]-10^{9}[5]$ of cancer cells.

A "suitable" biosensor needs to fulfil many requirements including: being reproducible, sensitive, specific, label-free, fast (ideally real-time), using small volumes of reagents and samples, operating in aqueous environment, versatile, (highly) parallel, low cost and also offering the possibility of miniaturization [14-17]. In fact, the major bottlenecks in cancer detection stem from 4 limitations:

1. Need for direct diagnosis of low-abundance markers [18] within a wide diversity of other biomolecules from a simple -possibly noninvasive- sampling method with a low false positive rate.

2. Limited selectivity favouring the rationale "many markers are better than one" [14, 16, 19, 20] even though no definitive combination of biomarkers exists yet [21, 22].

3. Need for detecting single cancer cells, rather than conventional bulk measurements [23, 24] reporting the ensemble average of several thousands of highly heterogeneous cells.

4. Need for an integrated, sensitive, highthroughput and low cost diagnostic platform.

Biosensors can be decomposed into 4 first steps: (1) the biological marker (in short: biomarkers) that needs to be detected, (2) the interface, a scaffold typically using high affinity ligands that provide specificity (3) the transducer - the sensing part of the device - which is sensitive to the presence of the biomolecule to be detected (4) the environment. Resulting analogue signals need then to be digitized, pre-processed and analysed.

\section{Biomarkers: Towards Circulating Tumour Cells}

Biomarkers are biomolecules (analytes) which are selected for being sensitive reporters of a specific state or its evolution such as: predisposition to a given disease, diagnosis, prognosis, treatment efficacy and follow-up. We are multicellular organisms composed of a large diversity of elements at different levels: 2900 endogenous or common metabolites (http://www.metabolomics.ca/), $\sim 10^{5}$ [25]-106 [26] proteins, 22,000 [13] genes, $\sim 300$ cell types [13], 4 tissues [27], and 12 organ systems [27] offering a large -daunting- panel of potential biomarkers.

In oncology, biomarkers can be circulating tumour DNA [28], mRNA transcripts [29, 30], polysomes [31, 32], miRNA [33], proteins [34, 35], metabolites [36], autoantibodies [37], etc [38]. Sources of biomarkers have been extended within this last decade following technological improvements in detection devices (e.g.: lower limit of detection, coupling with microfluidics) contributing to a strongly growing interest in biofluids [39]. Such progresses provide access to biomarkers expressed at low amounts in a heterogeneous population not only in plasma (which is the primary clinical source of biomarkers [18]), but also: serum, saliva [39-41] and tears [42] among others, as they contain potentially relevant analytes [18, 41], while being low cost and minimally invasive to collect [41]. 
Metastases, not the primary tumour, are responsible for most cancer deaths [43-45]. However, there is mounting evidence that at least in some cancer types (including breast cancer), metastasis may not be as late an event as previously thought [30, 43, 44, 46-49]. Expansion of the primary tumour is performed by clonogenic cancer cells ('seeds') which successfully disseminate via different routes [50] including the lymphatic and haematogenous ones [45]. They eventually settle to distant organs such as the bone marrow (a common site for their homing and survival independently of the primary tumour site [51]) liver, and lungs [52] where they keep on growing to overt metastases. Such cancer seeds include disseminated tumour cells in the bone marrow (DTCs) and circulating tumour cells (CTCs) $[45,51]$. In contrast to DTCs, we will focus on CTCs which are minimally invasive to collect (thus enabling the collection of time series) from circulating blood, a tissue of major diagnostic importance $[14,53]$ being in contact with all organs.

A major strategy for detecting circulating tumour cells in carcinomas is based on the Epithelial Cell Adhesion Molecule or EpCAM(CD326), the first human tumour-associated antigen recognized with a monoclonal antibody [54] in the late 70's [55, 56]. This glycoprotein of $\sim 40 \mathrm{kDalton}[57,58]$, containing 2 epidermal growth factor (EGF)-like domains in its extracellular domain [54], is frequently overexpressed in many cancers including: breast, colon, gastric, lung, ovarian, prostate and renal carcinomas [54, 58, 59]. This is consistent with increasing evidence of the role of EpCAM in tumour growth and progression [54]. Moreover, EpCAM (previously identified as Epithelial Specific Antigen (ESA), one of its many former synonyms [54]) has been suggested as a useful marker for isolating subsets of enriched tumour-initiating cells which may represent cancer stem cell [51, 60-62].

For a typical mammalian cell, with a radius of $\sim 10 \mu \mathrm{m}[63,64]$ (http://www.nanomedicine.com/), the maximum number of surface receptors of average radius of $5 \mathrm{~nm}$ (covering $25 \%$ of the cell's surface) is estimated to be $4.10^{6}$ from in vivo data [63]. The types of surface receptors a cell expresses may range from only a few $\sim 10-40$ (in large quantity $\sim 10^{5}$ ) to many receptors types $\sim 2,000-30,000$ (in low quantity $\sim 10^{2}$ ) [63] depending on the cell type, differentiation state and environment. Carcinoma cell line data indicates that the sensitivity of immunohistochemistry concerning the EpCAM marker may be limited. Indeed, prostate cell line PC3-9 are barely detected ( 51,000 antigens) and EpCAM presence on the human bladder cancer cells T24 ( 2,000 antigens) is missed [59]. Relying on flow cytometry with EpCAM to identify CTCs, a first alternative assay was developed: the CellSearch ${ }^{\circledR}$ System (developed by Immunicon Corporation in 2002 and bought in 2008 by Veridex, LLC, a Johnson \& Johnson company, New Brunswick, NJ) consisting of an automated immunomagnetic enrichment step followed by interpretation of stained samples with a semi-automated fluorescence microscope. With this technique, it was shown that the mean number of EpCAM molecules/CTC was $~ 50,000$ corresponding to a decrease by a factor 10 between primary and metastatic tissues. This has been attributed to the necessary down-regulation of EpCAM allowing the detachment of tumour cells from the primary tumour to eventually enter the circulation and form a metastasis [59]. The CellSearch ${ }^{\circledR}$ system was cleared by the FDA for metastatic breast in 2004, then for metastatic colorectal cancers in 2007. The FDA expanded its clearance in 2008 for monitoring metastatic prostate cancers, and is the most frequent system used in clinical trials nowadays to detect CTCs (see Table 1).

The study of Cristofanilli et al. [65], detecting CTCs in the peripheral blood of patients with metastatic breast cancer, suggested that CTCs were an independent predictor of progression-free survival and overall survival [66]. Additional patient data may further expand its application to a broader spectrum of cancers.

Detecting reliably rare events -a single circulating tumour cell in a background of as many as $10^{9}$ normal blood cells is challenging [67-69].

Table 1. Examples of Relatively Large (Patient Population >=100) Single Studies Assessing Circulating Tumour Cells (Pubmed Search, from 2004/09/19 Until 2009/02/17)

\begin{tabular}{|c|c|c|c|c|c|c|c|}
\hline Total No of Patients & Stage & Cancer Type & Recognition & Technique & Assay & Year & Reference \\
\hline \hline 964 & Metastatic & Prostate & EpCAM & Cytometry & CellSearch & 2004 & {$[134]$} \\
\hline 177 & Metastatic & Breast & EpCAM & Cytometry & CellSearch & 2004 & {$[65]$} \\
\hline 164 & Cancer & Melanoma & MCSP & Cytometry & ImmunoMagnetic & 2004 & {$[135]$} \\
\hline 177 & Metastatic & Breast & EpCAM & Cytometry & CellSearch & 2006 & {$[136]$} \\
\hline 138 & Metastatic & Breast & EpCAM & Cytometry & CellSearch & 2006 & {$[137]$} \\
\hline 144 & Cancer & Various & 52 markers screened & Nucleic-acid based & RT-PCR & 2007 & {$[138]$} \\
\hline 116 & Metastatic & Various & EpCAM & Cytometry & CTC-Chip & 2007 & {$[68]$} \\
\hline 231 & Metastatic & Prostate & EpCAM & Cytometry & CellSearch & 2008 & {$[66]$} \\
\hline 164 & Metastatic & Prostate & EpCAM & Cytometry & CellSearch & 2009 & {$[139]$} \\
\hline 155 & Cancer & Prostate & PSA/PSMA & Nucleic-acid based & RT-PCR & 2009 & {$[140]$} \\
\hline
\end{tabular}


The CTC chip developed by Nagrath et al. (see Table 1), also functionalized with EpCAM antibodies, is capable of detecting CTCs in lower concentration, higher purity and yield in a panel of non-haematologic cancers [68]. The CTC chip (with EpCAM antibodies) was also implemented in a small clinical trial $(n=27)$, identifying patients with metastatic non-small cell lung cancer that may develop drug-resistance to therapy [70]. Performing molecular analysis on DNA recovered from the CTCs, the authors were able to identify EGFR mutations. Although the dataset was limited, this study suggests some of the potential for providing precious molecular information concerning CTCs.

\section{Interface and High-Affinity Ligands}

Biosensors' interfaces are composed of a scaffold of chemical molecules with high-affinity ligands on the outer layer. The role of the interface is to link the highaffinity ligands to the transducer but also to play the role of a spacer between the sensing surface and the biomarker. This is necessary to permit or ease threedimensional molecular recognition between the analyte and the ligand. For instance, in the BIAcore ${ }^{\circledR}$ context, the role is played by a non-specific polymer, Carboxymethyl Dextran (a branched polysaccharide made of several glucose molecules). This functionalization is not optimum because the large thickness of the Dextran matrix $(\sim 100 \mathrm{~nm}$ thick) inherently limits the sensitivity of the technique (which decreases exponentially from the surface with a 1/e reduction in $\sim 500 \mathrm{~nm}$ ) hence a sub-optimal signal-tonoise ratio [71]. Although in most cases it is not an issue, this limitation may be reached in the case of very low molecular weight biomarkers $(<100 \mathrm{Da})$. Finally, the Dextran matrix is suspected to have a non-neutral role in measurements which may limit reproducibility [71]. There is an increasing interest in other scaffolds using a poly(ethylene glycol) or PEG layer. PEG is a linear polymer or oligomer with a molecular weight ranging essentially from $200 \mathrm{Da}$ to $20 \mathrm{kDa}$. Different functional groups can be linked at each chain end, making it a versatile non-fouling strategy widely used for biosensing but also for the vectorization of drugs as it reduces non-specific binding [72, 73].

Aptamers (derived from Latin aptus 'fitting' and merged with the Greek meros 'part') are novel and particularly interesting class of high affinity ligands, with the ability to bind to a variety of targets including peptides, enzymes, antibodies and cell surface receptors. Peptide aptamers are short single stranded sequences of amino acids (e.g.: 10) derived from combinatorial libraries through selective targeting in a process known as Systematic Evolution of Ligands by Exponential enrichment (SELEX). An example composed of a thioredoxin scaffold (blue) and a variable region of a few amino acids (red) is depicted in Fig. (1c). Peptide aptamers offer unique benefits compared to other ligands, in that they bind with high affinity and selectivity, are easily and quickly synthesized using in vitro techniques, are stable [74-
76]. Peptide aptamers can be chemically synthesized. They are not immunogenic or toxic and have a good clearance from the system. This abrogates the risk of carrying disease (unlike antibodies) as well as the need of specific ethical considerations in their production.

DNA, RNA and peptide aptamers are small [75] ( 10-20kDalton [9]) compared to antibodies (typically $\sim 150 \mathrm{kDalton}[63,77])$. This is a very attractive feature for biosensors (so called "aptasensors"), but also as targeting modalities for either imaging contrast agent or nanovectorization [76].

\section{Transduction Schemes for Biosensors}

Biosensors are designed so that the presence of a biomarker of interest induces a detectable shift of the signal (e.g.: change in mass, optical refractive index, resonance frequency). The transduction layer is responsible for the sensitivity of the device, sometimes enhanced by a label (e.g.: fluorescent or radioactive). Label-free transducers are either based on: (1) electrochemistry, (2) mechanics or (3) optics as depicted in Fig. (2).

Electrochemical sensors assess electron transfer between electrodes and species in solution (e.g.: based on changes in potential, current or impedance). Nanowires, with diameters between 10-20nm [17], are highly sensitive to changes in chemical potential with demonstrated ability to sense single or small panels of cancer serum biomarkers [78]. They are however limited by Debye screening [17, 78].

Mechanical transducers include surface acoustic wave, microcantilever and quartz crystal microbalance. Their limit of detection is in the low $\mathrm{ng} / \mathrm{cm}^{2}$ range [79]. The most promising transduction scheme seems to be microcantilevers since they can operate in liquid environment. These springboard-like microstructures (typical size: several hundreds of $\mu \mathrm{m}$ in length, $100 \mu \mathrm{m}$ width and 0.3-4 thick) [80] could detect prostatespecific antigen (PSA) in a controlled environment [81]. Limitations may arise from a lack of reproducible immobilization for antibodies and irreversible cantilever bending at room temperature following protein-antibody binding [17].

Label-free transduction by optical means relies on surface plasmon resonance (SPR) and ellipsometry. By far the most common transduction scheme is the surface plasmon resonance as integrated in the popular BIAcore ${ }^{\circledR}$ apparatuses. This approach is well established for characterizing biomolecular interactions, resulting in a large and increasing panel of SPR devices available such as Autolab, Lumera, GenOptics, Mivitec and Sensata sensors among others. With a limit of detection in the low $\mathrm{ng} / \mathrm{cm}^{2}$ range $[82,83]$, there is also a strong interest in this promising optical approach for biomarker detection [78]. As the signal decays exponentially from the gold surface within the first 200nm [84] probed, the closer to the sensing surface, the higher the signal. Therefore, reducing the 


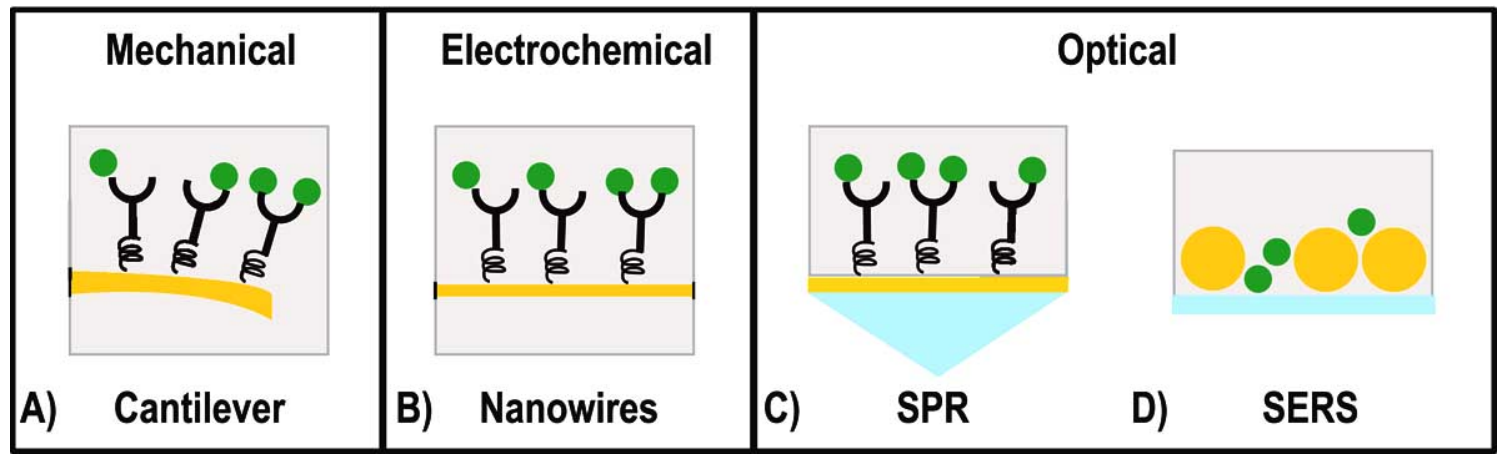

Fig. (2). Examples of label-free biosensors with a limit of detection in the low nanogram $/ \mathrm{cm}^{2}$ range currently under investigation for cancer research. High-affinity ligands are coupled to the transducer using a linker (e.g.: PEG). Therefore, upon binding, biomarkers of interest are detected by the induced signal variation from (A) a mechanical, (B) an electrochemical or (C) and (D) an optical origin. SPR: Surface Plasmon Resonance, SERS: Surface Enhanced Raman Scattering. In case (A), (B) and (C), specificity is provided by the high-affinity ligands whereas in example (D), a spectrum provides a chemical fingerprint. See text for further details.

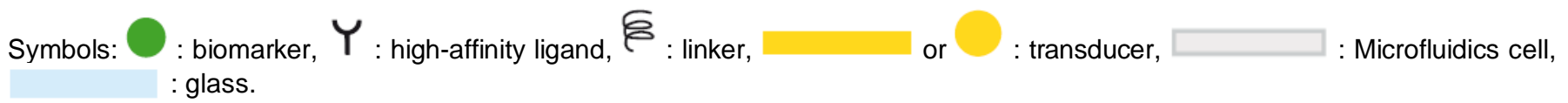

distance to, or the size of, the high-affinity ligand is important. Another caveat of SPR biosensors is its limited number of channels. An alternative is SPR imaging (SPRi), which consists in combining a chargecoupled device (CCD) camera. The improvement in the spatial resolution is substantial: a hundred of channels [85] or a thousand of sensing spots $[82,86]$ but well below the level of multiplexing achieved with microarray technology (several tens of thousands of features assessed in parallel). Discovered in 1928, the optical Raman Effect is inherently weak, with crosssections $\sim 10^{-25}-10^{-30} \mathrm{~cm}^{2}$ whereas fluorescence crosssections are $\sim 10^{-16}-10^{-17} \mathrm{~cm}^{2}[87,88]$. Thanks to nanotechnology, it has been revisited and enhanced by several orders in magnitude $\left(>10^{6}\right.$ [87]) since the 70's, making it an attractive sensor nowadays [42, 87, 88]. The Surface Enhanced Raman Scattering (SERS) is considered a powerful approach potentially able to reach single molecule detection [89]. Localized surface plasmon resonance requires a nanopatterned metal surface (e.g.: silver or gold) to exacerbate the electromagnetic field [89] in so-called "hot spots". Rough metallic substrate can be obtained by bottom-up (e.g.: aggregated nanoparticles of $10-100 \mathrm{~nm}$ in diameter [42]) or top-down (e.g.: electrochemistry, lithography) approaches. Key advantages of SERS are that measurements: (1) are non-destructive, (2) operate in liquid environment, (3) require little or no sample preparation, (4) do not necessarily require highaffinity ligands. The SERS signal provides vibrational spectra (i.e. chemical fingerprints), enabling the characterisation of biomarkers of interest thanks to chemometrics and machine learning algorithms [89]. Among the recent applications of SERS to cancer research, one can mention gold nanorods conjugated to anti-epidermal growth factor receptor antibodies to discriminate cancer cells human oral squamous cancer cells from human nonmalignant epithelial keratinocyte cells [90].

\section{Microfluidics}

Within these last few years, a microfluidics approach applied to cancer research is gaining interest [51]. Microfluidics devices, a spinoff from the microtechnologies, were first created in the 1990s for electrophoresis and offer a panel of interesting features for biological and medical applications [14, 91]. For these purposes, the most common material is the poly(dimethylsiloxane) or PDMS [92, 93]. It is non-toxic to cells, optically transparent, flexible and impermeable to water (but permeable to gases) [94, 95]. The microstructures obtained with this elastomeric polymer (e.g.: channels) are in the $1-1000 \mu \mathrm{m}$ range and $100 \mathrm{~nm}-100 \mu \mathrm{m}$ for lateral and vertical dimensions respectively $[92,93]$. The volume of fluids within the channels can thus be very small -usually in the order of nanoliters- which is 6 orders of magnitude less than what is normally used for ELISA tests, for instance. As a consequence, the necessary amount of reagents and analytes is reduced: a significant improvement for expensive reagents and/or samples. Moreover, the detection is faster: seconds compared to several hours required in ELISA tests, a key improvement for detection. In addition, the fabrication techniques used to construct microfluidics devices are relatively inexpensive [96] and are very amenable both to highly elaborated, multiplexed devices and also to mass production. In a manner similar to that for microelectronics, microfluidics technologies enable the fabrication of highly integrated devices for performing several different functions on the same substrate chip $[14,97]$. Micro-fluidics are by definition suited for handling living cells (which typical diameter is a few micrometers [63]) in a three-dimensional (3D), biologically relevant environment [92]. Microfluidic platforms are attractive strategies for developing assays (e.g.: diagnostics) and methods of cell culture, or drugs screening. One of the long term goals in the 
field of microfluidics is to create integrated labs-on-chip (loc), point-of-care devices (poc), and micro-Total Analysis Sytems ( $\mu$ TAS) for home and bedside use, thereby eliminating time consuming laboratory analysis procedures [83, 91].

A key advantage of microfluidics is its ability to mimic and control biological microenvironments [98, 99]. Cells (and to a lesser extent proteins) are indeed quite sensitive to a variety of cues [100, 101]. Hence the local control [102] of temperature, the composition of solutions but also shear stress are of a paramount importance $[68,103,104]$. Microfluidics offers interesting alternatives to current methods (e.g.: Petri dish, microtiter plates), which are in general macroscale techniques (dimensions $\sim \mathrm{cm}$ and larger) and afford a limited degree of microenvironmental control [105]. Approaches to mimic tumors in a microfluidics environment are emerging. Such threedimensional in vitro tumour models bridge the gap between 2D cultures and animal experiments [101] and represent an important tool for a better understanding of tumor growth and the optimization of intratumoral drug delivery [106] for instance [101].

\section{CANCER TREATMENT}

Once cancer has been diagnosed, treating the disease mostly relies on surgery, radiotherapy and chemotherapy, separately or in combination. Nanotechnology represents a great hope to improve cancer treatments by acting at least at two main levels: conferring new properties to a pharmaceutical agent (increased stability, modified pharmacokinetics, decreased toxicity...) and targeting the agent directly to the tumour. The first strategy provides a means to revisit selected new molecular entities which failed in the development process due to poor pharmaceutical properties (i.e.: $~ 40 \%$ of new molecular entities [107]). The goal is thus to increase the therapeutic index of known drugs $[9,108]$. A major bottleneck of chemotherapy (e.g.: systemic injection, oral administration) is the relative lack of specificity of anticancer drugs which affect tumour but also normal tissues, triggering undesirable side-effects. It is indeed estimated from in vivo data that out of 100,000 molecules administered intravenously, only 1 to 10 actually reach their target [15]. The use of drug delivery systems (DDSs), composed of a nanocarrier and its therapeutics, dramatically changes the physicochemical properties of the drug as well as its biodistribution [108]. This is particularly relevant in the case of very active drugs whose interest in the clinics is limited by their toxicity on vital organs (heart, kidneys, bone marrow...), but it may also provide new delivery options for existing drugs which are about to be offpatent [2]. The opportunity offered by nanotechnology is to take advantage of the leaky neovasculature of the tumour (i.e.: passive targeting), and possibly also of high-affinity ligands to target the tumour with a DDS (i.e.: active targeting) and deliver the drug locally, minimizing side effects.

\section{EPR Effect}

In the mid-80's, it was found that both primary and metastatic tumours exhibited anatomical and pathophysiological abnormalities which may improve drug delivery's efficacy by a mechanism called the Enhanced Permeability and Retention (EPR) effect [109]. When the growing tumour ( $2 \mathrm{~mm}$ in diameter) has activated the angiogenic switch, new vessels are being formed to supply oxygen and nutriments. However, since tumour cells have a more rapid proliferation rate than cells that form blood capillaries [110], the newly formed vasculature greatly differs from the normal one as it is dilated, irregular in shape, and leaky or defective, due to poorly organized endothelial cells which create large fenestrations [111, 112]. This contributes to the observed spatial and temporal heterogeneity in blood flow. A possible strategy to circumvent this problem and improve drug delivery consists in restoring the balance between an overexpression of proangiogenic molecules (e.g.: vascular endothelial growth factor or VEGF, a glycoprotein of $\sim 45 \mathrm{kDalton}$ [13]) and an underexpression of antiangiogenic molecules (e.g.: thrombospondin) in the endothelial cells [113]. This vascular normalization potentially leads to the restoration of structurally and functionally normal tumour vessels improving the delivery of oxygen and drugs, for radiotherapy and chemotherapy respectively, before tumour vasculature destruction [113]. However, without intervention, pressure caused by proliferating cancer cells forces vessels apart, reducing vascular density and creating areas of chronic hypoxia (when cells are distant from capillaries $>70 \mu \mathrm{m}$ [114] but less than $180 \mu \mathrm{m}$ [115]), decreasing blood and lymphatic flow. Altogether, these features create a tumour microenvironment with increased interstitial fluid pressure, hypoxia and acidosis. The large holes in the endothelial walls combined with a poor lymphatic drainage and a slow venous return result in a major leakage of blood and its components into the tumor ("swelling", in latin) tissue. Taking advantage of this EPR effect [108, 111, 112, 116] (see Fig. (3)), DDSs can progressively but selectively build up in the tumour to deliver drugs with local concentrations $10-50$ fold higher compared to normal tissue [111] or 10 fold and more compared to the same dose of free drug [108]. The drug is then released in the vicinity of the tumour cell and taken up into the cell.

The EPR effect can be increased with factors inducing tumour vascular permeability (e.g.: vascular permeability factor) or vasodilatation (e.g.: nitric oxide). Alternatively, taking advantage of the lack of smoothmuscle layer in tumour blood vessels, induction of a hypertensive state can exacerbate the EPR effect due to the vasoconstriction in healthy organs [111].

Drugs need to be stable in plasma for long durations since the EPR effect is cumulative, implying a long half-life and stealth feature to escape the elimination by the reticuloendothelial system or immune system [111]. Once delivered, such drugs must remain in tumour tissues for several days or months [111]. 

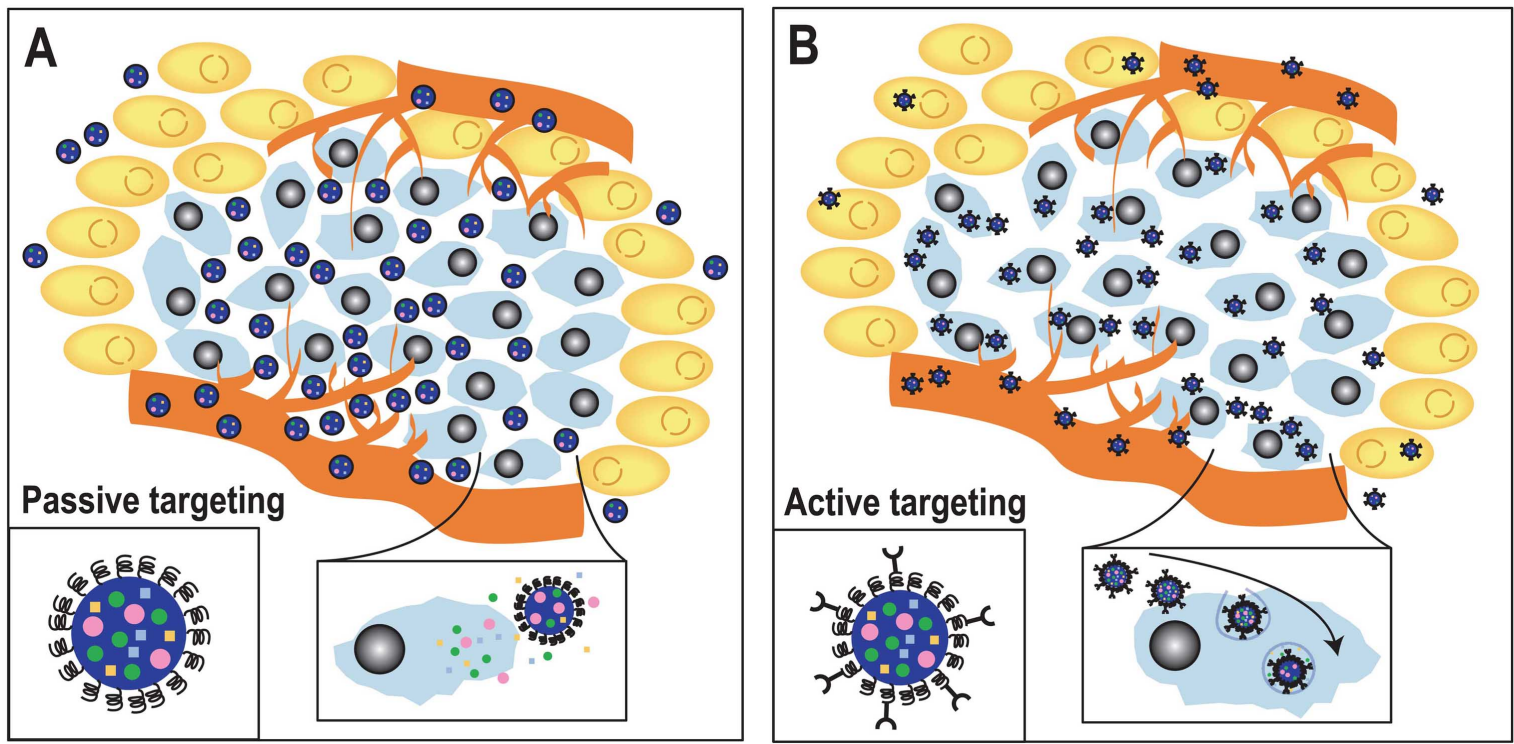

Fig. (3). Enhanced Permeability and Retention (EPR) effect: Systemic injection of nanoparticles can take advantage of the leaky nature of tumor vasculature: A) Passive EPR effect: nanoparticles with appropriate sizes tend to build-up preferentially in the tumor versus healthy tissue. Such nanoparticles can be loaded with contrast agents (squares) and/or drugs (circles) which are then delivered in the vicinity of cancer cells. B) Active EPR effect: nanoparticles targeted with high-affinity ligands (e.g.: fragments of antibodies or aptamers) can more selectively reach the tumor and be taken-up by cancer cells enabling intracellular drug delivery.

Targeted or non-targeted nanoparticles can be loaded with different drugs and/or contrast agent for chemotherapy and/or imaging purposes. The surface of functionalized nanoparticles can be decorated with "stealth" moieties such as polyethylene glycol (PEG), and high-affinity ligands for improved targeting specificity.

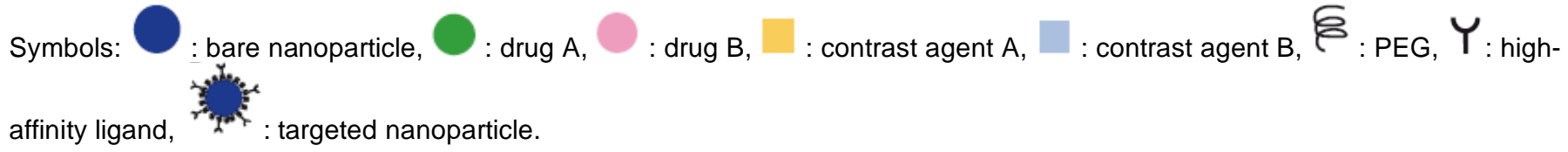

After separation from the nanocarrier, delivery of drugs within the intracellular space is often limited by the uptake by endocytosis, receptor-mediated or not. Uptake of drugs by diffusion may also occur but at a slower rate [111].

\section{Nanoparticles}

In oncology, clinically useful nanoparticles (NPs) have a diameter $\sim 10-100 \mathrm{~nm}$ [117] and are filled with drugs to provide new means of vectorization. This enables improving solubility which can be used either to revisit an existing drug with poor solubility or to protect the active molecule until it reaches the desired site of action. An additional advantage of NPs may be their increased loading capacity compared to molecular vectors. For instance, a $70 \mathrm{~nm}$ NP can contain 2,000siRNA drug molecules whereas antibody conjugates have less than 10 [78]. NPs can also be filled with contrast agents for imaging purposes.

Due to their small size, if properly designed, NPs can cross physiologic barriers, delivering drugs in normally inaccessible sites with classical means [2]. Utilization of NPs as vectors to target the tumour requires passing through neovessel's pores with diameters $<1 \mu \mathrm{m}$ range $[2,9]$. In vivo data from mice bearing human xenografts indicate pore diameters between 400-600 nm [118]. However, NPs with a diameter $>200 \mathrm{~nm}$ are not suitable since they activate the complement system which clears them [2].

The first nanocarrier, described about 40 years ago, was a liposome [9]. Liposomes, either natural or synthetic, can carry hydrophilic and hydrophobic molecules. The first FDA approved DDS was a liposome encapsulating doxorubicin. Nowadays, a large panel of NPs of different natures exists (see Table 2), some already approved by the FDA [117]. Polymeric nanoparticles may provide the most promising nanovectors for drug transportation. Among them, biodegradable ones are of particular interest since they can be metabolized and removed from the body [9]. An interesting example is the case of PLGA in which the relative amount of PLA (polylactic acid) and PGA (polyglycolic acid) can provide PLGA polymers with tuneable biodegradable properties. Adding polyethylene glycol (PEG) to the DDS's surface offers a hydrophilic "stealth" coating $[9,119]$.

To exacerbate the EPR effect and enhance intracellular uptake, high-affinity ligands can be functionalized on DDSs (so called active targeting). 
Small targeting moieties are suited so that single chain antibodies (with molecular weight $\sim 30 \mathrm{kDa}$ [77]), antibody fragments, peptides, peptide aptamers, folates, or sugars represent strategies often encountered [2, 9, 120].

Nanotechnology-based cancer drugs currently in clinical trials include liposomes, albumin-based, polymer-based, micelle and gold nanoparticles (Table 2).

Doxorubicin is an anticancer drug from the family of anthracyclins that inhibits the synthesis of nucleic acids within cancer cells. Its drawbacks include cardiotoxicity and myelosuppression [120]. PLGA nanoparticles conjugated with doxorubicin (diameter of 200-250 nm) have been investigated [120]. However, the current formulation is doxorubicin in PEG-coated liposomes $[78,121,122] \quad(\sim 100 \mathrm{~nm}$ of diameter, http://www.doxil.com/) known as Doxil ${ }^{\circledR}$ (Ortho Biotech Products) or Caelyx ${ }^{\circledR}$ (Schering-Plough) schematically represented in Fig. (4A). The cardiotoxicity of liposomal doxorubicin is decreased thanks to the DDS which reduces the peak cardiac level of the drug [108] resulting in more than 350 ongoing clinical trials (www.clinicaltrials.gov).

Paclitaxel $\left(\right.$ Taxol $^{\circledR}$, Bristol-Myers Squibb) belongs to the taxane drug family like Docetaxel (Taxotere ${ }^{\circledR}$, Sanofi Aventis). Paclitaxel promotes cell death by increasing the polymerization of tubulin hence provoking the disruption of cell division's dynamics [120]. This microtubule-stabilizing agent is however poorly soluble in aqueous solutions so its formulation includes Cremophor EL (polyethoxylated castor oil) and ethanol [123]. The former being cytotoxic and exhibiting side effects, new formulations were sought. Among them, different sizes of biodegradable nanoparticles made of PLGA [120]. Current formulations include a $130 \mathrm{~nm}$ albumin-bound particle form of paclitaxel (Abraxane ${ }^{\circledR}$, Abraxis Bioscience), administered without the use of other excipients [123]. Abraxane ${ }^{\circledR}$, schematically represented in Fig. (4B), targets tumors through the endothelial gp60 receptor and the albuminbinding protein overexpressed in a majority of tumors: the Secreted Protein Acidic and Rich in Cysteine (SPARC) [124] and was shown to be twice as effective as $\operatorname{Taxol}^{\circledR}$ [2]. Other formulations have been developed, including the Paclitaxel loaded polymeric micelle (Genexol-PM ${ }^{\circledR}$, Samyang), a taxane formulations that do not require Cremophor EL as a solubilizer [125] which is shown in Fig. (4C).

In the context of DNA topoisomerase I inhibitors, XMT-1001 (Mersana Therapeutics) is a novel polymeric pro-drug derivative of camptothecin. Camptothecin is chemically tethered to a hydrophilic, biodegradable polymer (see Fig. (4D)). This strategy has improved the solubility and pharmacokinetics of Camptothecin, resulting in a Phase I clinical trial [126].

Contrasting with examples based on hollow or porous nano-objects (e.g.: liposome, micelle), solid gold nanoparticles (with diameter $\sim 30 \mathrm{~nm}$ [124]) were functionalized with recombinant human tumor necrosis factor alpha (TNFalpha), giving rise to Aurimune ${ }^{\circledR}$ (Cytlmmune Sciences), represented in Fig. (4E). The surface of colloidal gold NPs are pegylated so that the therapeutic payload travels safely through the blood stream avoiding immune detection and is preferentially delivered to the site of disease (http://www.cytimmune. $\mathrm{com} /$ ).

In order to improve drug bioavailability, different means for triggering drug release are currently under investigation. Activation of the drug can either depend on endogenous properties such as abnormally low $\mathrm{pH}$ values or exogenous cues like temperature, magnetic field, light, radiofrequency, or presence of an analyte $[9,108]$.

Drug delivery systems are designed to accumulate preferentially in the tumour (10 fold higher or more [111]), but a portion of them also accumulates in the host. After intravenous injection of a DDS, the most frequent side-effect seems to be a hypersensitivity

Table 2. Applications of Different Types of Nanoparticles as Drug Delivery Systems for Treating Solid Cancers from http://www.cancer.gov/ (Last Access $28^{\text {th }}$ of October 2009)

\begin{tabular}{|c|c|c|c|c|}
\hline Nanoparticles & Name (Synonym) & Therapeutic Agent & $\begin{array}{c}\text { Stage of } \\
\text { Development }\end{array}$ & Cancer Types \\
\hline \hline \multirow{2}{*}{ Liposome } & Doxil $^{\circledast}$ & Doxorubicin hydrochloride & FDA approved & $\begin{array}{c}\text { Several trials assessing different types } \\
\text { of solid tumors }\end{array}$ \\
\hline Polymer-based & $\begin{array}{c}\text { Abraxane } \\
\text { (ABI 007) }\end{array}$ & Paclitaxel & FDA approved & $\begin{array}{c}\text { Several trials assessing different types } \\
\text { of solid tumors }\end{array}$ \\
\hline \multirow{2}{*}{ Micelle } & Paclical $^{\circledR}$ & Camptothecin & Phase I & Solid tumors \\
\cline { 2 - 5 } & $\begin{array}{c}\text { Genexol } \\
\text { Paclitaxel-Loaded } \\
\text { Polymeric Micelle }\end{array}$ & Paclitaxel & Phase III & Ovarian \\
\hline Gold & $\begin{array}{c}\text { Aurimune } \\
\text { (CYT-6091) }\end{array}$ & $\begin{array}{c}\text { Pecombinant human tumor } \\
\text { necrosis factor (TNF) }\end{array}$ & Phase I/II & Ovarian \\
\hline
\end{tabular}




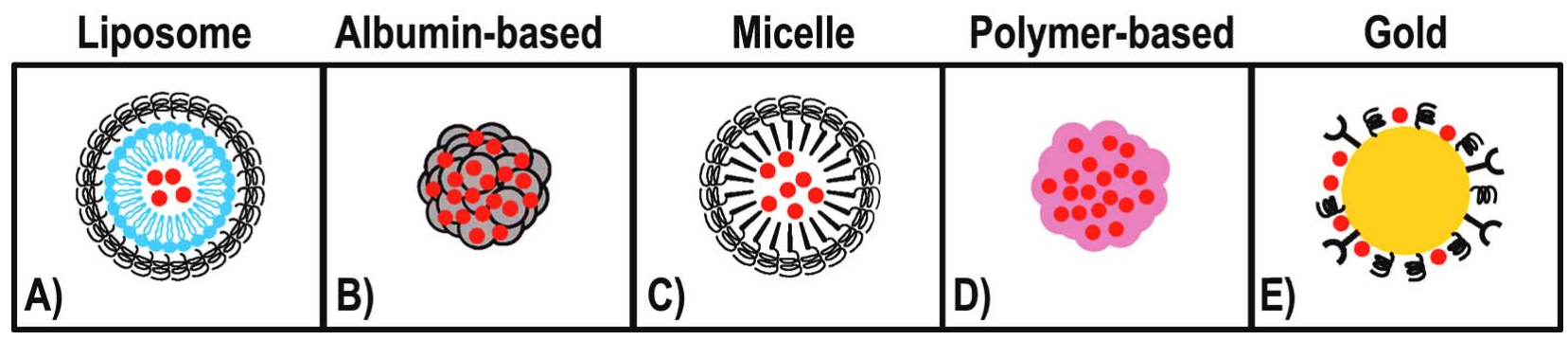

Fig. (4). Schematic of the different classes of drug delivery systems currently investigated in clinical trials (from Table $\mathbf{2}$, see text for further details).

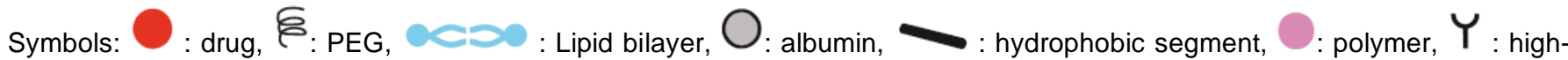
affinity ligand.

reaction which may result from the activation of the complement [108]. Because DDSs tend to build-up in the mononuclear phagocyte system (especially into the liver, spleen and bone marrow), toxicity (e.g.: production of reactive oxygen species [127, 128]) may occur in these tissues [108]. Besides, since in essence 'the dose makes the poison' [124, 129, 130], additional toxicity issues concerning these nanocarriers need to be carefully addressed to evaluate the risk/benefit ratio as they may hamper widespread use of NPs in current practice [128, 131-133]. In this direction, the Nanotechnology Characterization Laboratory has developed an assay cascade protocol lasting approximately one year, to carefully characterize nanoparticles' physicochemical attributes, their in vitro biological properties, and their in vivo compatibility using animal models (http://ncl.cancer.gov/).

\section{CONCLUDING REMARKS}

From the perspective of nanomedicine, an updated view of the cancer "magic bullet" envisioned by Paul Ehrlich, Nobel Prize in Physiology or Medicine in 1908 and father of the chemotherapy, may integrate detection, imaging and treatment modalities, providing unprecedented technical achievements towards improved devices for early cancer detection, treatment and patient follow-up. However, since the behaviour of these highly versatile nano-objects remains difficult to predict to date, a careful assessment of the toxicity and biodistribution remains critical. A unifying framework for these assays is emerging.

A tremendous amount of data has been collected since 1971, so that a critical step will be its translation into useful knowledge and concrete breakthrough. However, this necessary translation and validation of research findings via clinical trials is affected by critical barriers which are currently being identified. They include the administrative burden, creating very long delays ( $~ 800$ days) between concept and initiation of a clinical trial; the difficulty to enrol patients with as little as $\sim 3 \%$ of patients participating to cancer clinical trials; or the small amount of published registered clinical trials (less than $\sim 20 \%$ out of $\sim 2,000$ registered clinical trials at ClinicalTrials.gov) so a lot of potentially important data is not accessible. Going down to the nanoscale is certainly essential, but there are probably also other dimensions to consider if we are to win the "war on cancer".

\section{ACKNOWLEDGEMENTS}

This paper is dedicated to M-A Moravie who passed away due to a lung cancer at the age of 37 . We thank C. Seigneuric, JP Delord for helpful comments on the manuscript. Conception and design: R. Seigneuric, C.T.A. Evelo, C. Garrido. Analysis and interpretation of data: R. Seigneuric, L. Markey, D.S.A. Nuyten, C. Dubernet, C.T.A. Evelo, E. Finot, C. Garrido. Drafting the article: R. Seigneuric, L. Markey, E. Finot, C. Garrido. Revising it critically for important intellectual content: R. Seigneuric, L. Markey, D.S.A. Nuyten, C. Dubernet, C.T.A. Evelo, E. Finot, C. Garrido. Final approval of the version to be published: R. Seigneuric, L. Markey, D.S.A. Nuyten, C. Dubernet, C.T.A. Evelo, E. Finot, C. Garrido. Disclosure: The authors have no conflict of interest to declare except C. Garrido who has a European patent concerning aptamers (INSERM Technology transfer, 2007-2008). For D.S.A. Nuyten, this review is on a topic of personal interest and does not reflect the opinions of Bristol-Myers Squibb Company. This work was supported by the INSERM and grants from the 'label d'excellence de la Ligue Nationale Contre le Cancer'.

\section{ABBREVIATIONS}

CCD $=$ Charge-Coupled Device
DDS $=$ Drug Delivery System
ELISA $=$ Enzyme-Linked Immunosorbent Assay
EPR $=$ Enhanced Permeability and Retention
FDA $=$ Food
HSP $=$ Heat Shock Protein
LoC $=$ Lab-on-chip
$\mu$ TAS $=$ Micro-Total Analysis Sytems




$\begin{array}{ll}\text { NP } & =\text { Nano-Particle } \\ \text { PDMS } & =\text { Poly(dimethylsiloxane) } \\ \text { PEG } & =\text { Poly(ethylene glycol) } \\ \text { poc } & =\text { Point-of-care } \\ \text { PSA } & =\text { Prostate-specific Antigen } \\ \text { SERS } & =\text { Surface Enhanced Raman Scattering } \\ \text { SPR } & =\text { Surface Plasmon Resonance } \\ \text { SPRi } & =\text { Surface Plasmon Resonance imaging }\end{array}$

\section{REFERENCES}

[1] Drexler KE. Molecular engineering: An approach to the development of general capabilities for molecular manipulation. Proc Natl Acad Sci USA 1981; 78(9): 5275-8.

[2] Emerich DF, Thanos CG. The pinpoint promise of nanoparticle-based drug delivery and molecular diagnosis. Biomol Eng 2006; 23(4): 171-84.

[3] Moghimi SM, Kissel T. Particulate nanomedicines. Adv Drug Deliv Rev 2006; 58(14): 1451-5.

[4] Nanotechnology: A Report of the U.S. Food and Drug Administration Nanotechnology Task Force. Rockville MD 2007.

[5] Cancer Nanotechnology plan: A Strategic Initiative to Transform Clinical Oncology and Basic Research through the Directed Application of Nanotechnology: National Institutes of Health \& National Cancer Institute 2004.

[6] Langer R. Drug delivery. Drugs on target. Science 2001; 293(5527): 58-9.

[7] Tanaka T, Decuzzi P, Cristofanilli M, et al. Nanotechnology for breast cancer therapy. Biomed Microdevices 2009; 11(1): 49-63.

[8] Murthy SK. Nanoparticles in modern medicine: state of the art and future challenges. Int J Nanomed 2007; 2(2): 129-41.

[9] Alexis F, Rhee JW, Richie JP, Radovic-Moreno AF, Langer $\mathrm{R}$, Farokhzad OC. New frontiers in nanotechnology for cancer treatment. Urol Oncol 2008; 26(1): 74-85.

[10] Sporn MB. The war on cancer: a review. Ann N Y Acad Sci 1997; 833: 137-46.

[11] Potti A, Schilsky RL, Nevins JR. Refocusing the war on cancer: the critical role of personalized treatment. Sci Transl Med 2010; 2(28): 28cm13.

[12] Kim KY. Nanotechnology platforms and physiological challenges for cancer therapeutics. Nanomedicine 2007; 3(2): 103-10.

[13] Weinberg RA. The Biology of Cancer. New York: Garland Scientific; 2006.

[14] Hood L, Heath JR, Phelps ME, Lin B. Systems biology and new technologies enable predictive and preventative medicine. Science 2004; 306(5696): 640-3.

[15] Ferrari M. Cancer nanotechnology: opportunities and challenges. Nat Rev Cancer 2005; 5(3): 161-71.

[16] van der Greef J, Stroobant P, van der Heijden R. The role of analytical sciences in medical systems biology. Curr Opin Chem Biol 2004; 8(5): 559-65.

[17] Cheng MM, Cuda G, Bunimovich YL, et al. Nanotechnologies for biomolecular detection and medical diagnostics. Curr Opin Chem Biol 2006; 10(1): 11-9.

[18] Anderson NL, Anderson NG. The human plasma proteome: history, character, and diagnostic prospects. Mol Cell Proteomics 2002; 1(11): 845-67.

[19] Vogelstein B, Kinzler KW. Cancer genes and the pathways they control. Nat Med 2004; 10(8): 789-99.

[20] Geho DH, Luchini A, Garaci E, Belluco C, Petricoin E, Liotta LA. Nanotechnology in clinical proteomics. Nanomedicine (Lond) 2007 ; 2(1): 1-5.

[21] Fung G, Seigneuric R, Krishnan S, Rao RB, Wouters BG, Lambin $P$. Reducing a Biomarkers List via Mathematical Programming: Application to Gene Signatures to Detect
Time-Dependent Hypoxia in Cancer. In: Sixth International Conference on Machine Learning and Applications (ICMLA 2007); 2007; 2007. p. 482-487.

[22] Seigneuric R, van Riel NAW, Starmans MHW, et al. Systems Biology Applied to Cancer Research. In: Daskalaki A, editor. Handbook of Research on Systems Biology Applications in Medicine. Hershey, N.Y.: Medical Information science reference; 2009. p. 339-353.

[23] Di Carlo D, Lee LP. Dynamic single-cell analysis for quantitative biology. Anal Chem 2006; 78(23): 7918-25.

[24] Toriello NM, Douglas ES, Thaitrong N, et al. Integrated microfluidic bioprocessor for single-cell gene expression analysis. Proc Natl Acad Sci USA 2008; 105(51): 20173-8.

[25] Hunter PJ, Borg TK. Integration from proteins to organs: the Physiome Project. Nat Rev Mol Cell Biol 2003; 4(3): 237-43.

[26] Oh JE, Krapfenbauer K, Fountoulakis M, Frischer T, Lubec G. Evidence for the existence of hypothetical proteins in human bronchial epithelial, fibroblast, amnion, lymphocyte, mesothelial and kidney cell lines. Amino Acids 2004; 26(1): 9-18.

[27] Hunter P, Smith N, Fernandez J, Tawhai M. Integration from proteins to organs: the IUPS Physiome Project. Mech Ageing Dev 2005; 126(1): 187-92.

[28] Diehl F, Schmidt K, Choti MA, et al. Circulating mutant DNA to assess tumor dynamics. Nat Med 2008; 14(9): 985-90.

[29] Seigneuric R, Starmans MH, Fung G, et al. Impact of supervised gene signatures of early hypoxia on patient survival. Radiother Oncol 2007; 83(3): 374-82.

[30] van 't Veer LJ, Dai $H$, van de Vijver MJ, et al. Gene expression profiling predicts clinical outcome of breast cancer. Nature 2002; 415(6871): 530-6.

[31] Koritzinsky M, Magagnin MG, van den Beucken $T$, et al. Gene expression during acute and prolonged hypoxia is regulated by distinct mechanisms of translational control. Embo J 2006; 25(5): 1114-25.

[32] Koritzinsky $M$, Seigneuric $R$, Magagnin $M G$, van den Beucken T, Lambin P, Wouters BG. The hypoxic proteome is influenced by gene-specific changes in mRNA translation. Radiother Oncol 2005; 76(2): 177-86.

[33] Croce CM. Oncogenes and cancer. N Engl J Med 2008; 358(5): 502-11.

[34] Hanash S. Disease proteomics. Nature 2003; 422(6928): 226-32.

[35] Magagnin MG, Sergeant $K$, van den Beucken $T$, et al. Proteomic analysis of gene expression following hypoxia and reoxygenation reveals proteins involved in the recovery from endoplasmic reticulum and oxidative stress. Radiother Oncol 2007; 83(3): 340-5.

[36] Ellis DI, Dunn WB, Griffin JL, Allwood JW, Goodacre R. Metabolic fingerprinting as a diagnostic tool. Pharmacogenomics 2007; 8(9): 1243-66.

[37] Fujita $Y$, Nakanishi T, Miyamoto $Y$, et al. Proteomics-based identification of autoantibody against heat shock protein 70 as a diagnostic marker in esophageal squamous cell carcinoma. Cancer Lett 2008; 263(2): 280-90.

[38] Sawyers CL. The cancer biomarker problem. Nature 2008; 452(7187): 548-52.

[39] Fabian TK, Fejerdy P, Csermely P. Salivary Genomics, Transcriptomics and Proteomics: The Emerging Concept of the Oral Ecosystem and their Use in the Early Diagnosis of Cancer and other Diseases. Curr Genomics 2008; 9(1): 11 21.

[40] Tan W, Sabet L, Li Y, et al. Optical protein sensor for detecting cancer markers in saliva. Biosens Bioelectron 2008; 24(2): 266-71.

[41] Wong DT. Salivary diagnostics powered by nanotechnologies, proteomics and genomics. J Am Dent Assoc 2006; 137(3): 313-21.

[42] Reyes-Goddard JM, Barr H, Stone N. Surface enhanced Raman scattering of herpes simplex virus in tear film. Photodiagnosis Photodyn Ther 2008; 5(1): 42-9.

[43] Husemann Y, Geigl JB, Schubert F, et al. Systemic spread is an early step in breast cancer. Cancer Cell 2008; 13(1): 5868. 
[44] Weigelt B, Peterse JL, van 't Veer LJ. Breast cancer metastasis: markers and models. Nat Rev Cancer 2005; 5(8): 591-602.

[45] Pantel K, Brakenhoff RH. Dissecting the metastatic cascade. Nat Rev Cancer 2004; 4(6): 448-56.

[46] Bernards R, Weinberg RA. A progression puzzle. Nature 2002; 418(6900): 823.

[47] Podsypanina K, Du YC, Jechlinger M, Beverly LJ, Hambardzumyan D, Varmus $H$. Seeding and propagation of untransformed mouse mammary cells in the lung. Science 2008; 321(5897): 1841-4.

[48] van de Vijver MJ, He YD, van't Veer LJ, et al. A geneexpression signature as a predictor of survival in breast cancer. N Engl J Med 2002; 347(25): 1999-2009.

[49] Ramaswamy S, Ross KN, Lander ES, Golub TR. A molecular signature of metastasis in primary solid tumors. Nat Genet 2003; 33(1): 49-54.

[50] Eccles SA, Welch DR. Metastasis: recent discoveries and novel treatment strategies. Lancet 2007; 369(9574): 174257.

[51] Pantel K, Brakenhoff RH, Brandt B. Detection, clinical relevance and specific biological properties of disseminating tumour cells. Nat Rev Cancer 2008; 8(5): 329-40.

[52] Braun S, Naume B. Circulating and disseminated tumor cells. $\mathrm{J}$ Clin Oncol 2005; 23(8): 1623-6.

[53] Liotta LA, Ferrari M, Petricoin E. Clinical proteomics: written in blood. Nature 2003; 425(6961): 905.

[54] Baeuerle PA, Gires O. EpCAM (CD326) finding its role in cancer. Br J Cancer 2007; 96(3): 417-23.

[55] Herlyn M, Steplewski Z, Herlyn D, Koprowski H. Colorectal carcinoma-specific antigen: detection by means of monoclonal antibodies. Proc Natl Acad Sci USA 1979; 76(3): 1438-42.

[56] Koprowski H, Steplewski Z, Herlyn D, Herlyn M. Study of antibodies against human melanoma produced by somatic cell hybrids. Proc Natl Acad Sci USA 1978; 75(7): 3405-9.

[57] Trzpis M, McLaughlin PM, de Leij LM, Harmsen MC. Epithelial cell adhesion molecule: more than a carcinoma marker and adhesion molecule. Am J Pathol 2007; 171(2): 386-95.

[58] Balzar M, Winter MJ, de Boer CJ, Litvinov SV. The biology of the 17-1A antigen (Ep-CAM). J Mol Med 1999; 77(10): 699712.

[59] Rao CG, Chianese D, Doyle GV, et al. Expression of epithelial cell adhesion molecule in carcinoma cells present in blood and primary and metastatic tumors. Int $\mathrm{J}$ Oncol 2005; 27(1): 49-57.

[60] Al-Hajj M, Wicha MS, Benito-Hernandez A, Morrison SJ, Clarke MF. Prospective identification of tumorigenic breast cancer cells. Proc Natl Acad Sci USA 2003; 100(7): 3983-8.

[61] Visvader JE, Lindeman GJ. Cancer stem cells in solid tumours: accumulating evidence and unresolved questions. Nat Rev Cancer 2008; 8(10): 755-68.

[62] Zhou BB, Zhang H, Damelin M, Geles KG, Grindley JC, Dirks PB. Tumour-initiating cells: challenges and opportunities for anticancer drug discovery. Nat Rev Drug Discov 2009; 8(10): 806-23.

[63] Papin JA, Hunter T, Palsson BO, Subramaniam S. Reconstruction of cellular signalling networks and analysis of their properties. Nat Rev Mol Cell Biol 2005; 6(2): 99-111.

[64] DePasquale JA, Samsonoff WA, Gierthy JF. 17-betaEstradiol induced alterations of cell-matrix and intercellular adhesions in a human mammary carcinoma cell line. J Cell Sci 1994; 107 (Pt 5): 1241-54.

[65] Cristofanilli M, Budd GT, Ellis MJ, et al. Circulating tumor cells, disease progression, and survival in metastatic breast cancer. N Engl J Med 2004; 351(8): 781-91.

[66] de Bono JS, Scher HI, Montgomery RB, et al. Circulating tumor cells predict survival benefit from treatment in metastatic castration-resistant prostate cancer. Clin Cancer Res 2008; 14(19): 6302-9.

[67] Krivacic RT, Ladanyi A, Curry DN, et al. A rare-cell detector for cancer. Proc Natl Acad Sci USA 2004; 101(29): 10501-4.
[68] Nagrath S, Sequist LV, Maheswaran S, et al. Isolation of rare circulating tumour cells in cancer patients by microchip technology. Nature 2007; 450(7173): 1235-9.

[69] Gross HJ, Verwer B, Houck D, Hoffman RA, Recktenwald D. Model study detecting breast cancer cells in peripheral blood mononuclear cells at frequencies as low as 10(-7). Proc Natl Acad Sci USA 1995; 92(2): 537-41.

[70] Maheswaran S, Sequist LV, Nagrath S, CV, et al. Detection of mutations in EGFR in circulating lung-cancer cells. N Engl J Med 2008; 359(4): 366-77.

[71] Masson JF, Battaglia TM, Khairallah P, Beaudoin S, Booksh KS. Quantitative measurement of cardiac markers in undiluted serum. Anal Chem 2007; 79(2): 612-9.

[72] Uchida K, Otsuka H, Kaneko M, Kataoka K, Nagasaki Y. A reactive poly(ethylene glycol) layer to achieve specific surface plasmon resonance sensing with a high $S / N$ ratio: the substantial role of a short underbrushed PEG layer in minimizing nonspecific adsorption. Anal Chem 2005; 77(4): 1075-80.

[73] Cortez C, Tomaskovic-Crook E, Johnston AP, et al. Influence of size, surface, cell line, and kinetic properties on the specific binding of $\mathrm{A} 33$ antigen-targeted multilayered particles and capsules to colorectal cancer cells. ACS Nano 2007; 1(2): 93-102.

[74] Davis JJ, Tkac J, Laurenson S, Ko Ferrigno P. Peptide aptamers in label-free protein detection: 1. Characterization of the immobilized scaffold. Anal Chem 2007; 79(3): 108996.

[75] Baines IC, Colas P. Peptide aptamers as guides for smallmolecule drug discovery. Drug Discov Today 2006; 11(7-8): 334-41.

[76] Farokhzad OC, Cheng J, Teply BA, et al. Targeted nanoparticle-aptamer bioconjugates for cancer chemotherapy in vivo. Proc Natl Acad Sci USA 2006; 103(16): 6315-20.

[77] Ladner RC. Antibodies cut down to size. Nat Biotechnol 2007; 25(8): 875-7.

[78] Heath JR, Davis ME. Nanotechnology and cancer. Annu Rev Med 2008; 59: 251-65.

[79] Legay G. Analyse locale des sensibilités des lectures angulaires, spectroscopiques et ellipsométriques de la Résonance des Plasmons de Surface en vue de la miniaturisation des biocapteurs optiques. Dijon: Université de Bourgogne; 2006.

[80] Braun T, Ghatkesar MK. Measuring the intrinsic nanomechanics of molecular interactions with microcantilever. Eur J Nanomed 2009; 2: 13-15.

[81] $\mathrm{Wu} G$, Datar RH, Hansen KM, Thundat T, Cote RJ, Majumdar A. Bioassay of prostate-specific antigen (PSA) using microcantilevers. Nat Biotechnol 2001; 19(9): 856-60.

[82] Campbell CT, Kim G. SPR microscopy and its applications to high-throughput analyses of biomolecular binding events and their kinetics. Biomaterials 2007; 28(15): 2380-92.

[83] Hoa XD, Kirk AG, Tabrizian M. Towards integrated and sensitive surface plasmon resonance biosensors: a review of recent progress. Biosens Bioelectron 2007; 23(2): 151-60.

[84] Jung LS, Campbell CT, Chinowsky TM, Mar MN, Sinclair SY. Quantitative interpretation of the response of surface plasmon resonance sensors to adsorbed films. Langmuir 1998; 14: 5636-48.

[85] Piliarik $M$, Vaisocherova $H$, Homola J. A new surface plasmon resonance sensor for high-throughput screening applications. Biosens Bioelectron 2005; 20(10): 2104-10.

[86] Lausted C, Hu Z, Hood L. Quantitative serum proteomics from surface plasmon resonance imaging. Mol Cell Proteomics 2008; 7(12): 2464-74.

[87] Scaffidi JP, Gregas MK, Seewaldt V, Vo-Dinh T. SERSbased plasmonic nanobiosensing in single living cells. Anal Bioanal Chem 2009; 393(4): 1135-41.

[88] Kneipp L. Surface-enhanced Raman scaterring. Am J Phys 2007: 40-46.

[89] Goodacre R, Jarvis RM. Applications in bioprocesses and biotechnology. Eur Pharmaceut Rev 2005(4): 72-7. 
[90] Huang X, El-Sayed IH, Qian W, El-Sayed MA. Cancer cells assemble and align gold nanorods conjugated to antibodies to produce highly enhanced, sharp, and polarized surface Raman spectra: a potential cancer diagnostic marker. Nano Lett $2007 ; 7(6)$ : $1591-7$.

[91] El-Ali J, Sorger PK, Jensen KF. Cells on chips. Nature 2006; 442(7101): 403-11.

[92] Weibel DB, Diluzio WR, Whitesides GM. Microfabrication meets microbiology. Nat Rev Microbiol 2007; 5(3): 209-18.

[93] McDonald JC, Whitesides GM. Poly(dimethylsiloxane) as a material for fabricating microfluidic devices. Acc Chem Res 2002; 35(7): 491-9.

[94] Whitesides GM. The origins and the future of microfluidics. Nature 2006; 442(7101): 368-73.

[95] Jönsson H. Microfluidics for lab-on-chip applications: Lund Graduate School of Biomedical Research; 2002.

[96] Quake SR, Scherer A. From micro- to nanofabrication with soft materials. Science 2000; 290(5496): 1536-40.

[97] Beebe DJ, Mensing GA, Walker GM. Physics and applications of microfluidics in biology. Annu Rev Biomed Eng 2002; 4: 261-86.

[98] Chen CS, Mrksich M, Huang S, Whitesides GM, Ingber DE. Geometric control of cell life and death. Science 1997; 276(5317): 1425-8.

[99] Cukierman E, Pankov R, Stevens DR, Yamada KM. Taking cell-matrix adhesions to the third dimension. Science 2001; 294(5547): 1708-12.

[100] Discher DE, Janmey P, Wang YL. Tissue cells feel and respond to the stiffness of their substrate. Science 2005; 310(5751): 1139-43.

[101] Yamada KM, Cukierman E. Modeling tissue morphogenesis and cancer in 3D. Cell 2007; 130(4): 601-10.

[102] Nilsson J, Evander M, Hammarstrom B, Laurell T. Review of cell and particle trapping in microfluidic systems. Anal Chim Acta 2009; 649(2): 141-57.

[103] Green JV, Kniazeva T, Abedi M, Sokhey DS, Taslim ME, Murthy SK. Effect of channel geometry on cell adhesion in microfluidic devices. Lab Chip 2009; 9(5): 677-85.

[104] Adams AA, Okagbare PI, Feng J, et al. Highly efficient circulating tumor cell isolation from whole blood and labelfree enumeration using polymer-based microfluidics with an integrated conductivity sensor. J Am Chem Soc 2008; 130(27): 8633-41.

[105] Paguirigan AL, Beebe DJ. Microfluidics meet cell biology: bridging the gap by validation and application of microscale techniques for cell biological assays. Bioessays 2008; 30(9): 811-21.

[106] Kim B, Han G, Toley BJ, Kim CK, Rotello VM, Forbes NS. Tuning payload delivery in tumour cylindroids using gold nanoparticles. Nat Nanotechnol 2010; 5(6): 465-72.

[107] Devalapally H, Chakilam A, Amiji MM. Role of nanotechnology in pharmaceutical product development. $\mathrm{J}$ Pharm Sci 2007; 96(10): 2547-65.

[108] Allen TM, Cullis PR. Drug delivery systems: entering the mainstream. Science 2004; 303(5665): 1818-22.

[109] Matsumura Y, Maeda H. A new concept for macromolecular therapeutics in cancer chemotherapy: mechanism of tumoritropic accumulation of proteins and the antitumor agent smancs. Cancer Res 1986; 46(12 Pt 1): 6387-92.

[110] Minchinton Al, Tannock IF. Drug penetration in solid tumours. Nat Rev Cancer 2006; 6(8): 583-92.

[111] lyer AK, Khaled G, Fang J, Maeda H. Exploiting the enhanced permeability and retention effect for tumor targeting. Drug Discov Today 2006; 11(17-18): 812-8.

[112] Jain RK. Normalization of tumor vasculature: an emerging concept in antiangiogenic therapy. Science 2005; 307(5706): 58-62.

[113] Jain RK. Normalizing tumor vasculature with anti-angiogenic therapy: a new paradigm for combination therapy. Nat Med 2001; 7(9): 987-9.

[114] Vaupel P, Harrison L. Tumor hypoxia: causative factors, compensatory mechanisms, and cellular response. Oncologist 2004; 9 Suppl 5: 4-9.
[115] Harris AL. Hypoxia--a key regulatory factor in tumour growth. Nat Rev Cancer 2002; 2(1): 38-47.

[116] Davis AJ, Tannock IF. Tumor physiology and resistance to chemotherapy: repopulation and drug penetration. Cancer Treat Res 2002; 112: 1-26.

[117] Davis ME, Chen ZG, Shin DM. Nanoparticle therapeutics: an emerging treatment modality for cancer. Nat Rev Drug Discov 2008; 7(9): 771-82.

[118] Yuan F, Dellian M, Fukumura D, et al. Vascular permeability in a human tumor xenograft: molecular size dependence and cutoff size. Cancer Res 1995; 55(17): 3752-6.

[119] Liu Y, Miyoshi H, Nakamura M. Nanomedicine for drug delivery and imaging: a promising avenue for cancer therapy and diagnosis using targeted functional nanoparticles. Int $\mathrm{J}$ Cancer 2007; 120(12): 2527-37.

[120] Brannon-Peppas L, Blanchette JO. Nanoparticle and targeted systems for cancer therapy. Adv Drug Deliv Rev 2004; 56(11): 1649-59.

[121] Torchilin VP. Passive and active drug targeting: drug delivery to tumors as an example. Handb Exp Pharmacol 2010; (197): 3-53.

[122] Torchilin VP. Recent advances with liposomes as pharmaceutical carriers. Nat Rev Drug Discov 2005; 4(2): 145-60.

[123] Green MR, Manikhas GM, Orlov S, et al. Abraxane, a novel Cremophor-free, albumin-bound particle form of paclitaxel for the treatment of advanced non-small-cell lung cancer. Ann Oncol 2006; 17(8): 1263-8.

[124] Wei C, Liu N, Xu P, et al. From bench to bedside: successful translational nanomedicine: highlights of the Third Annual Meeting of the American Academy of Nanomedicine. Nanomedicine 2007; 3(4): 322-31.

[125] Kim TY, Kim DW, Chung JY, et al. Phase I and pharmacokinetic study of Genexol-PM, a cremophor-free, polymeric micelle-formulated paclitaxel, in patients with advanced malignancies. Clin Cancer Res 2004; 10(11): 3708-16.

[126] Yurkovetskiy AV, Fram RJ. XMT-1001, a novel polymeric camptothecin pro-drug in clinical development for patients with advanced cancer. Adv Drug Deliv Rev 2009; 61(13): 1193-202.

[127] Nel AE, Madler L, Velegol D, et al. Understanding biophysicochemical interactions at the nano-bio interface. Nat Mater 2009; 8(7): 543-57.

[128] Donaldson K, Seaton A. The Janus faces of nanoparticles. J Nanosci Nanotechnol 2007; 7(12): 4607-11.

[129] Lüllmann $\mathrm{H}$, Mohr K ZA, Bieger D. Color Atlas of Pharmacology 1993: 369.

[130] Seigneuric RG, Chasse JL, Auger P, Bardou A. Simulated interactions between a Class III antiarrhythmic drug and a figure 8 reentry. Acta Biotheor 2005; 53(4): 265-75.

[131] Kostarelos K. The long and short of carbon nanotube toxicity. Nat Biotechnol 2008; 26(7): 774-6.

[132] Medina C, Santos-Martinez MJ, Radomski A, Corrigan OI, Radomski MW. Nanoparticles: pharmacological and toxicological significance. Br J Pharmacol 2007; 150(5): 5528.

[133] Vega-Villa KR, Takemoto JK, Yanez JA, Remsberg CM, Forrest ML, Davies NM. Clinical toxicities of nanocarrier systems. Adv Drug Deliv Rev 2008; 60(8): 929-38.

[134] Allard WJ, Matera J, Miller MC, et al. Tumor cells circulate in the peripheral blood of all major carcinomas but not in healthy subjects or patients with nonmalignant diseases. Clin Cancer Res 2004; 10(20): 6897-904.

[135] Ulmer A, Schmidt-Kittler O, Fischer J, et al. Immunomagnetic enrichment, genomic characterization, and prognostic impact of circulating melanoma cells. Clin Cancer Res 2004; 10(2): 531-7.

[136] Hayes DF, Cristofanilli M, Budd GT, et al. Circulating tumor cells at each follow-up time point during therapy of metastatic breast cancer patients predict progression-free and overall survival. Clin Cancer Res 2006; $12(14$ Pt 1): 4218-24. 
[137] Budd GT, Cristofanilli M, Ellis MJ, et al. Circulating tumor cells versus imaging--predicting overall survival in metastatic breast cancer. Clin Cancer Res 2006; 12(21): 6403-9.

[138] Xi L, Nicastri DG, El-Hefnawy T, Hughes SJ, Luketich JD, Godfrey TE. Optimal markers for real-time quantitative reverse transcription PCR detection of circulating tumor cells from melanoma, breast, colon, esophageal, head and neck, and lung cancers. Clin Chem 2007; 53(7): 1206-15.
[139] Scher HI, Jia X, de Bono JS, et al. Circulating tumour cells as prognostic markers in progressive, castration-resistant prostate cancer: a reanalysis of IMMC38 trial data. Lancet Oncol 2009; 10(3): 233-9.

[140] Eschwege P, Moutereau S, Droupy S, et al. Prognostic value of prostate circulating cells detection in prostate cancer patients: a prospective study. Br J Cancer 2009; 100(4): 60810 